\title{
The lupus syndrome induced by hydralazine: a common complication with low dose treatment
}

\author{
H A CAMERON, L E RAMSAY
}

\begin{abstract}
The true incidence of the lupus syndrome induced by hydralazine was determined in a longitudinal study of 281 patients consecutively starting hydralazine for hypertension over a 51 month period. Data on the duration of treatment and the maximum dose achieved were examined using life table analysis. After three years' treatment with hydralazine the incidence of the lupus syndrome was $6.7 \%$ (95\% confidence limits $3 \cdot 2-10 \cdot 2 \%$ ). The incidence was dose dependent, with no cases recorded in patients taking $50 \mathrm{mg}$ daily and incidences of $5.4 \%$ with $100 \mathrm{mg}$ daily and of $10.4 \%$ with $200 \mathrm{mg}$ daily. The incidence was higher in women $(11.6 \%)$ than in men $(2.8 \%)$. In women taking $200 \mathrm{mg}$ daily the three year incidence was $19 \cdot 4 \%$.

Hydralazine is an effective antihypertensive drug that has come to be used in restricted dosage (not more than $200 \mathrm{mg}$ daily) because of its risk of inducing the lupus syndrome. This study shows that the true incidence of the syndrome is still unacceptably high even when the drug is prescribed according to current recommendations.
\end{abstract}

\section{Introduction}

The peripheral vasodilator hydralazine is commonly added to antihypertensive treatment when a combination of a $\beta$ blocker and a thiazide diuretic has failed to control the blood pressure. Used in this way it proved to be superior to labetalol, minoxidil, methyldopa, and prazosin over a six month period. ${ }^{1}$ With more prolonged treatment hydralazine, particularly at high dosage, may cause a syndrome resembling systemic lupus erythematosus. ${ }^{2}$ In recent years the maximum daily dose of hydralazine has usually been limited to $200 \mathrm{mg}$ to avoid the lupus syndrome, which has generally been believed to be rare with these lower doses. ${ }^{3}$ With this dosage limitation the incidence of the lupus syndrome has been estimated at $1.2 \%{ }^{4}$ and $3 \%{ }^{5}$ These figures, however, were derived from cross sectional surveys, which would tend to underestimate the true incidence. ${ }^{6}$ We report the incidence of the lupus syndrome in consecutive patients treated with hydralazine for hypertension.

\section{Patients and methods}

We studied 281 hypertensive patients who were consecutively prescribed hydralazine in the Sheffield hypertension clinic from October 1978 to December 1982. Hydralazine was used as a third or fourth drug, usually added to a $\beta$ blocker plus diuretic. In accordance with the manufacturer's data sheet ${ }^{7}$ it was started without knowledge of the patients' acetylator phenotype, and the antinuclear factor (titre) was not measured unless there was clinical suspicion of the

\footnotetext{
University Department of Therapeutics, Royal Hallamshire Hospital, Sheffield S10 2JF

H A CAMERON, BSC, MRCP, research registrar

L E RAMSAY, MB, FRCP, consultant physician and reader in clinical pharmacology and therapeutics

Correspondence to: Dr Cameron.
}

lupus syndrome. Hydralazine was started at $25 \mathrm{mg}$ twice daily and increased as necessary to $50 \mathrm{mg}$ or $100 \mathrm{mg}$ twice daily. In four patients the dose was increased to $400 \mathrm{mg}$ daily during a clinical trial; all four were rapid acetylators, and none developed the lupus syndrome. For ease of presentation they are included here with patients treated with $200 \mathrm{mg}$ daily.

The censoring date for the study was 30 June 1983, so that the duration of follow up was six to 57 months. Patients were followed up to the censoring date, until hydralazine was stopped, or until the lupus syndrome developed. Thirty five patients $(12 \%)$ were lost to follow up because of default or discharge from the clinic. These patients were assumed to have continued hydralazine at the same dose and to have remained free from the lupus syndrome. Any error arising from this would underestimate the true incidence of the lupus syndrome.

The lupus syndrome was diagnosed from 10 clinical or laboratory features (see table I) ${ }^{2}$ The diagnosis was difficult in only one patient, who is described briefly below. The daily dose of hydralazine used in the analysis was the highest dose taken for three months or longer. For each patient the duration of treatment with hydralazine was calculated and the data were subjected to life table analysis using the KaplanMeier method. ${ }^{8}$ Ninety five per cent confidence limits for estimates of incidence were calculated by the method of Armitage when the sample size permitted. ${ }^{9}$ The analysis was not carried beyond three years' treatment as the sample size was insufficient after this time.

\section{Results}

Of the 281 patients starting hydralazine, 146 were men and 135 were women. The mean age was 57 years (range 32-77), and the mean (SD) blood pressure was $191(27) / 109(13) \mathrm{mm} \mathrm{Hg}$. The mean duration of follow up was 24.4 months (range five days to 57 months). At the censoring date $192\left(68^{\circ}\right.$ ) patients were still taking hydralazine. The drug had been stopped in $40(14 \%)$ patients because of non-immune side effects (17), death (14), or non-response (two) or because it was no longer required (seven). There was nothing to suggest that any of the deaths were caused by the lupus syndrome. The maximum daily dose of hydralazine was $50 \mathrm{mg}$ in $82\left(29^{\circ}\right)$ patients, $100 \mathrm{mg}$ in $72\left(26^{\circ}{ }_{0}\right)$, and $200 \mathrm{mg}$ in $127\left(45^{\circ}\right)$. Fourteen patients $\left(5^{\circ} \%\right)$ developed the lupus syndrome.

\section{CLINICAL FEATURES OF THE LUPUS SYNDROME}

Table I shows the clinical features of the syndrome. The 14 patients with the syndrome had on average five (range two to eight) of the 10 features analysed. Diagnosis was difficult in one patient (case 7), a woman aged 65 . She presented with general ill health and a skin eruption of six weeks' duration. Hydralazine had been started 16 months previously, and she was taking $200 \mathrm{mg}$ daily. The skin lesions were a florid acquired livedo reticularis (fig 1), erythematous and urticarial lesions, facial telangiectasia, and acrocyanosis. The erythrocyte sedimentation rate was $93 \mathrm{~mm}$ in the first hour; the antinuclear factor titre was negative; double stranded DNA titre was 80 (of borderline importance); and she was a rapid acetylator. Cutaneous vasculitis was diagnosed and confirmed by a dermatologist, who considered biopsy to be unnecessary because the features were so typical. All manifestations resolved rapidly after hydralazine was stopped. This patient was atypical because the titre of antinuclear factor was negative and the lupus syndrome is rare in rapid acetylators. The illness could be termed hydralazine induced cutaneous vasculitis rather than the lupus syndrome, but we considered it to be a variant of the lupus syndrome.

At the time of diagnosis symptoms of the lupus syndrome had been present for a mean of three months (range one to nine). Eight patients were ill enough to require admission to hospital, with a mean stay of 17 days. In addition to the clinical features given in table I six patients had renal impairment during the illness, with urinary abnormalities in 
four. All the clinical and laboratory features resolved after hydralazine was stopped, with the exception of the high titre of antinuclear factor, which declined but in some cases did not fall to zero.

\section{INCIDENCE OF THE LUPUS SYNDROME}

Figure 2 (top) shows the life table analysis for all 281 patients. The first case was diagnosed after nine months' treatment and the last case after $\mathbf{4 0}$ months. At $\mathbf{4 0}$ months the incidence of the lupus syndrome was $7 \cdot 2^{\circ}$, with $95^{\circ}$, confidence limits $3 \cdot 6-10 \cdot 8^{\circ}$, . Figure 2 (bottom) shows the life table analysis according to sex. The incidence at three years was higher in women $(11.6 \% ; 95 \%$ confidence limits $4.8-18.4 \%)$ than in men $\left(2 \cdot 8^{\circ}{ }_{0}\right)$. Table II shows the relations between sex, duration of treatment, and dose of hydralazine. The incidence of lupus was clearly dose related, with no cases in patients taking $50 \mathrm{mg}$ daily and with incidences of $5.4 \%$ in those taking $100 \mathrm{mg}$ daily and $10.4 \%$ (95 $\%$ confidence limits $4 \cdot 3-16 \cdot 5^{\circ} \%$ ) in those taking $200 \mathrm{mg}$ daily. In

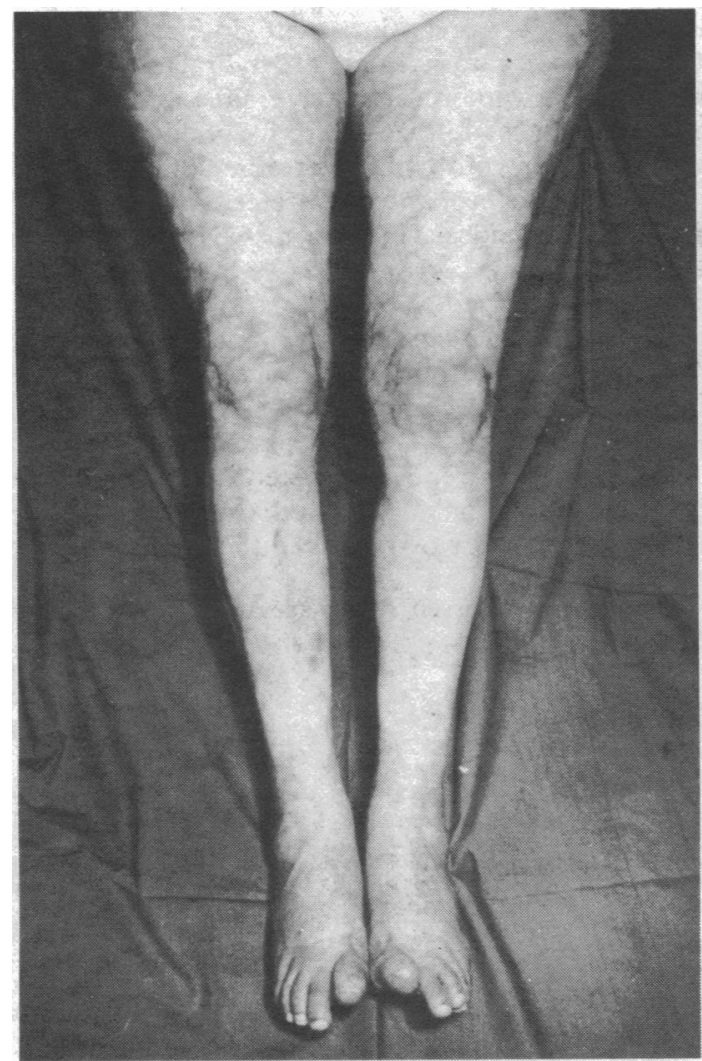

FIG 1 - Florid acquired livedo reticularis in patient with the lupus syndrome induced by hydralazine (case 7 ). men the syndrome occurred only with $200 \mathrm{mg}$ daily, with an incidence of $4.9 \%$. Women treated with $200 \mathrm{mg}$ daily had a high incidence $(19.4 \%)$, and even in women taking $100 \mathrm{mg}$ daily the incidence was higher $(8.0 \%)$ than that in men taking $200 \mathrm{mg}$.

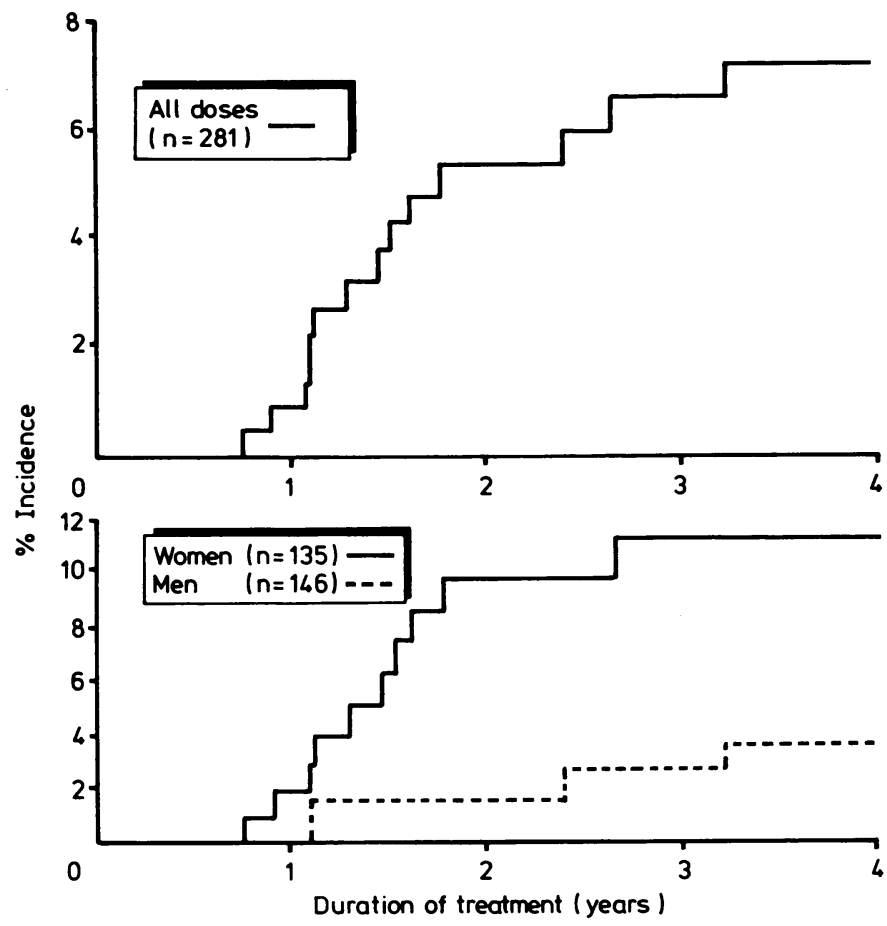

FIG 2-Life table analysis showing incidence of the lupus syndrome during treatment with hydralazine (all doses). Top: Incidence in all patients. Bottom: Incidence according to sex.

TABLE II-Incidence of the lupus syndrome induced by hydralazine. (All figures are percentages, with $95 \%$ confidence limits where calculable)

\begin{tabular}{|c|c|c|c|c|}
\hline Dosage (given twice daily) & $\begin{array}{c}\text { No of } \\
\text { patients }\end{array}$ & At 1 year & At 2 years & At 3 years \\
\hline $\begin{array}{l}\text { All patients: } \\
\text { All doses }\end{array}$ & 281 & 0.9 & \multirow{2}{*}{$\begin{array}{c}5 \cdot 5 \\
(2 \cdot 4-8 \cdot 6) \\
0 \\
3 \cdot 4 \\
9 \cdot 0\end{array}$} & \multirow{2}{*}{$\begin{array}{c}6 \cdot 7 \\
(3 \cdot 2-10 \cdot 2) \\
0 \\
5 \cdot 4 \\
10 \cdot 4 \\
(4 \cdot 3-16 \cdot 5)\end{array}$} \\
\hline $\begin{array}{l}25 \mathrm{mg} \\
50 \mathrm{mg} \\
100 \mathrm{mg}\end{array}$ & $\begin{array}{r}82 \\
72 \\
127\end{array}$ & $\begin{array}{l}0 \\
0 \\
1 \cdot 7\end{array}$ & & \\
\hline $\begin{array}{l}\text { Men: } \\
\text { All doses } \\
25 \text { or } 50 \mathrm{mg} \\
100 \mathrm{mg}\end{array}$ & $\begin{array}{r}146 \\
69 \\
77\end{array}$ & $\begin{array}{l}0 \\
0 \\
0\end{array}$ & $\begin{array}{l}1 \cdot 8 \\
0 \\
3 \cdot 2\end{array}$ & $\begin{array}{l}2 \cdot 8 \\
0 \\
4 \cdot 9\end{array}$ \\
\hline $\begin{array}{l}\text { Women: } \\
\text { All doses }\end{array}$ & 135 & 1.9 & $9 \cdot 9$ & \multirow{2}{*}{$\begin{array}{c}11 \cdot 6 \\
(4 \cdot 8-18 \cdot 4) \\
5 \cdot 5 \\
19 \cdot 4\end{array}$} \\
\hline $\begin{array}{l}25 \text { or } 50 \mathrm{mg} \\
100 \mathrm{mg}\end{array}$ & $\begin{array}{l}85 \\
50\end{array}$ & $\begin{array}{l}0 \\
4.5\end{array}$ & $\begin{array}{r}3.5 \\
18.9\end{array}$ & \\
\hline
\end{tabular}

TABLE I-Details of patients in whom the lupus syndrome was induced by hydralazine

\begin{tabular}{|c|c|c|c|c|c|c|c|c|c|c|c|c|c|c|c|}
\hline \multirow[b]{3}{*}{$\begin{array}{l}\text { Case } \\
\text { No }\end{array}$} & \multirow[b]{3}{*}{$\begin{array}{c}\text { Age } \\
\text { (years) }\end{array}$} & \multirow[b]{3}{*}{ Sex } & \multirow{3}{*}{$\begin{array}{c}\text { Duration of } \\
\text { symptoms } \\
\text { (months) }\end{array}$} & \multirow{2}{*}{\multicolumn{7}{|c|}{ Clinical features }} & \multicolumn{3}{|c|}{ Investigations } & \multirow{3}{*}{$\begin{array}{c}\text { Maximum } \\
\text { dose (mg } \\
\text { twice } \\
\text { daily) }\end{array}$} & \multirow{3}{*}{$\begin{array}{c}\text { Acetylator } \\
\text { state }\end{array}$} \\
\hline & & & & & & & & & & & \multirow{2}{*}{$\begin{array}{c}\text { Peak } \\
\text { ESR } \\
(\mathrm{mm} \text { in } \\
\text { lst h) }\end{array}$} & \multirow{2}{*}{$\begin{array}{c}\text { Peak } \\
\text { antinuclear } \\
\text { factor } \\
\text { titre }\end{array}$} & \multirow{2}{*}{$\begin{array}{l}\text { Lowest } \\
\text { haemoglobin } \\
(\mathrm{g} / \mathrm{dl})\end{array}$} & & \\
\hline & & & & Fever & $\begin{array}{c}\text { Joint } \\
\text { symptoms }\end{array}$ & Rash & $\begin{array}{c}\text { Weight } \\
\text { loss (kg) }\end{array}$ & $\begin{array}{l}\text { Spleno- } \\
\text { megaly }\end{array}$ & Pleurisy & $\begin{array}{c}\text { Peri- } \\
\text { carditis }\end{array}$ & & & & & \\
\hline $\begin{array}{c}1 \\
2 \\
3 \\
4 \\
5^{*} \\
6 \\
7 \\
8 \\
9 \\
10 \\
11 \\
12 \\
13 \\
14\end{array}$ & $\begin{array}{l}58 \\
54 \\
71 \\
53 \\
64 \\
51 \\
65 \\
58 \\
63 \\
65 \\
67 \\
45 \\
60 \\
52\end{array}$ & $\begin{array}{l}M \\
\mathrm{~F} \\
\mathrm{~F} \\
\mathrm{M} \\
\mathrm{F} \\
\mathrm{F} \\
\mathrm{F} \\
\mathrm{F} \\
\mathrm{M} \\
\mathrm{F} \\
\mathrm{F} \\
\mathrm{F} \\
\mathrm{F} \\
\mathrm{M}\end{array}$ & $\begin{array}{l}6 \\
2 \\
5 \\
1 \\
9 \\
5 \\
1 \cdot 5 \\
3 \\
2 \\
3 \\
1 \\
1 \\
1 \\
3\end{array}$ & $\begin{array}{l}+ \\
+ \\
+ \\
+\end{array}$ & $\begin{array}{l}+ \\
+ \\
+ \\
+ \\
+ \\
+ \\
+\end{array}$ & $\cdot+$ & $\begin{array}{c}6 \\
5 \cdot 4 \\
6 \\
0 \cdot 8 \\
7 \\
7 \\
\mathrm{Nil} \\
2 \cdot 5 \\
7 \\
12 \\
5 \\
\mathrm{Nil} \\
\mathrm{Nil} \\
4 \cdot 9\end{array}$ & $\begin{array}{l}+ \\
+\end{array}$ & $\begin{array}{l}+ \\
+\end{array}$ & + & $\begin{array}{r}125 \\
109 \\
87 \\
52 \\
23 \\
85 \\
93 \\
63 \\
40 \\
130 \\
124 \\
48 \\
30 \\
73\end{array}$ & $\begin{array}{r}500 \\
300 \\
1000 \\
1000 \\
1000 \\
500 \\
0 \\
500 \\
1000 \\
500 \\
500 \\
500 \\
500 \\
1000\end{array}$ & $\begin{array}{r}8.2 \\
10.8 \\
6.0 \\
11.9 \\
16.0 \\
11.2 \\
13.5 \\
10.7 \\
12.5 \\
7.8 \\
11.3 \\
13.3 \\
13.3 \\
13.0\end{array}$ & $\begin{array}{r}100 \\
100 \\
100 \\
100 \\
100 \\
50 \\
100 \\
100 \\
100 \\
50 \\
100 \\
100 \\
50 \\
100\end{array}$ & $\begin{array}{l}\text { Slow } \\
\text { Slow } \\
\text { ? } \\
\text { Slow } \\
\text { Slow } \\
\text { Slow } \\
\text { Rapid } \\
\text { Slow } \\
\text { Slow } \\
\text { Sllow } \\
\text { Slow } \\
\text { Slow } \\
\text { Slow } \\
\text { ? }\end{array}$ \\
\hline
\end{tabular}

ESR $=$ Erythrocyte sedimentation rate.

ESR = Erythrocyte sedimentation rate.
Patient seen three months after hydralazine was stopped; clinically improved at time of investigation. 


\section{Discussion}

These findings confirm many well known facts about hydralazine induced lupus. The syndrome is dose related, ${ }^{2}$ is commoner in women than men, ${ }^{4}$ and tends to develop after at least three months of treatment. ${ }^{2}$ The clinical and laboratory features were typical of those described previously. ${ }^{2}$ The only point of note was that six of the 14 patients had evidence of renal impairment. Until recently it was thought that hydralazine induced lupus spared the kidney, but renal disease has been recognised increasingly. ${ }^{10}$

The diagnosis of the lupus syndrome was straightforward in all but one case. This patient clearly had hydralazine induced cutaneous vasculitis ${ }^{11}$ but had no other features of the lupus syndrome. In particular, the titre of antinuclear factor was negative and she was a rapid acetylator. Hydralazine induced lupus was thought originally to occur only in slow acetylators. ${ }^{2}$ It is undoubtedly very rare in rapid acetylators, but cases have been described, ${ }^{12}$ and in these the patients also had atypical clinical features.

Hydralazine induced lupus syndrome is a serious adverse reaction. Although the diagnosis was finally straightforward, it was delayed by an average of three months from the onset of symptoms, and sometimes by as long as nine months. This was in patients under the care of doctors with an interest in the condition. The onset is often insidious, and the patient's complaints are often vague. Most patients were ill enough to require admission to hospital, and in at least two patients malignancy was diagnosed initially. ${ }^{13}$

The importance of this study is that it defines the trie incidence of the lupus syndrome when the drug is used at doses of not more than $200 \mathrm{mg}$ daily. Previous estimates of $1.2 \%$ and $30{ }^{5}$ were derived from cross sectional surveys that probably underestimated the real incidence. ${ }^{6}$ In the cohort of patients studied here the incidence of the lupus syndrome was $6.7 \%$ after three years, and the lower $95 \%$ confidence limit shows that the true incidence is unlikely to be less than $3 \cdot 2 \%$. This also suggests that the previous estimates were considerably in error, ${ }^{4}$ although the doses of hydralazine used in the different populations may be relevant.

The safety of long term hydralazine treatment is clearly related to the sex of the patient and the dose of the drug. A dose of $50 \mathrm{mg}$ daily appears to be safe in both sexes. In men $100 \mathrm{mg}$ daily caused no lupus but there was a $4.9 \%$ incidence with $200 \mathrm{mg}$ daily. In women $100 \mathrm{mg}$ daily was associated with an incidence of $8^{\circ} \mathrm{o}$, and $200 \mathrm{mg}$ daily with the remarkable figure of $19 \cdot 4 \%$.

Hydralazine fell into disfavour in the United Kingdom partly because of the high incidence of the lupus syndrome when it was used at high doses. When its use was resumed in the past decade the dose was limited to $200 \mathrm{mg}$ daily specifically to avoid the syndrome. This study shows that the incidence of the syndrome is still unacceptably high when hydralazine is used according to current recommendations. An incidence of $19.4 \%$ in women taking $200 \mathrm{mg}$ daily is obviously unacceptable, and in our view the incidences in women taking $100 \mathrm{mg}$ daily $(8 \%)$ and in men taking $200 \mathrm{mg}$ daily $(4.9 \%)$ are also too high. What can be done to reduce this risk? Four possible methods need to be considered-namely, further dose limitation, selection of patients, early detection, and use of alternative drugs.

Further dose limitation-There would not have been any cases of the lupus syndrome if the daily dose had been limited to $100 \mathrm{mg}$ in men and $50 \mathrm{mg}$ in women. Hydralazine is unlikely, however, to be a sufficiently effective antihypertensive drug at
these doses. ${ }^{11415}$

Selection of patients-Hydralazine induced lupus syndrome would be rare if the drug was restricted to rapid acetylators.
Although measurement of acetylator phenotype is simple, it is not readily available to general practitioners, who treat most cases of hypertension. More importantly, hydralazine would be denied to at least half of all patients in the United Kingdomthe slow acetylators - and they are the patients who respond best to the drug. ${ }^{16}$ The rapid acetylators who would receive hydralazine tend to have unsatisfactory responses. ${ }^{17}$

Early detection of the lupus syndrome-Regular monitoring of serum antinuclear factor titres might be considered. This would be expensive and inconvenient and is not a particularly accurate method of detection: about half of patients develop positive antinuclear factor titres during hydralazine treatment, ${ }^{4}$ and most do not deveiop the lupus syndrome. An alternative method is to detect symptoms early by warning patients, perhaps by a written warning card. Patients reporting suspicious symptoms could then be monitored closely and their antinuclear factor titre and erythrocyte sedimentation rate investigated. This, however, might be alarming to patients and might lead to unnecessary investigation of minor symptoms of no importance.

Use of alternative drugs - In short term studies hydralazine has proved superior to prazosin, methyldopa, minoxidil, and labetalol. ${ }^{1}$ Prazosin came closest to hydralazine, with similar efficacy and slightly more subjective side effects. ${ }^{1}$ When the subjective side effects of prazosin are weighed against the risk of the lupus syndrome with hydralazine the choice becomes close, and prazosin should probably be preferred in women. Nifedipine, captopril, and endralazine may prove to be suitable alternatives, but satisfactory comparative studies against hydralazine have not been performed.

In conclusion, the incidence of the lupus syndrome induced by hydralazine seems unacceptably high when the drug is prescribed according to current recommendations. The dose should be limited to $100 \mathrm{mg}$ daily, and patients should be followed up closely and advised to report persistent ill health, joint pains, weight loss, rash, chest pain, or any other unexplained symptom. Prazosin should probably be preferred to hydralazine in women.

We are grateful to Janssen Pharmaceutical Limited for financial support for HAC.

\section{References}

'McAreavey D, Ramsay LE, Latham L, et al. "Third drug" trial comparative study of antihypertensive agents added to treatment when blood pressure remain Perry HM. Late toxicity to hydralazine resembinretic. Br Med F 1984;288:106-11. or rheum. Late toxicity to hydralazine resembling systemic lupus erythematosus or rheumatoid arthritis. Am $\mathcal{f}$ Med 1973;54:58-72.
British national formulary. London: British

British national formulary. London: British Medical Association and PharmaMansilla-Tinoco R, Harland S J, Ryan .

bodies and the lupus land SJ, Ryan PJ, et al. Hydralazine, antinuclear antiBing RF, Russell Gus syndrome. Br Med f 1982;284:936-9.

there a safe dose? Br Med $\Im$ 1980;281:353-4

Ramsay LE, Silas J, Freestone $S$. Hydralazine, antinuclear antibodies and the
lupus syndrome. Br Med 7 1982;284:1711 Association of British Pharmaceutical

Association of British Pharmaceutical Industries. Data sheet compendium. London:
Datapharm Publications, 1983 .

- Kaplan EL, Meier P. Nonparametric estimation from incomplete observations
Journal of the American Statistical Association 1958;53:457-81. Armitage P. Statistical methods in medical research. Oxford: Blackwell Scientific Publications, 1977.

jörck S, Westburg G, Svalander C, Mulec H. Rapidly progressive glomerulonephritis after hydralazine. Lancet 1983 ;ii:42.

Bernstein RM, Egerton-Vernon J, Webster J. Hydralazine-induced cutaneous
vasculitis. Br Med $7980 ; 280 \cdot 156-7$

Harland SJ, Facchini V, Timbrell JA. H

like syndrome in a patient of the 273-4.

${ }^{13}$ Freestone S, Ramsay LE. Transient monoclonal gammopathy in hydralazineinduced lupus erythematosus. Br Med $\mathcal{F} 1982 ; 285: 1536-7$.

Ramsay LE, Silas JH, Ollerenshaw JD, Tucker GT, Phillips FC, Freestone $S$ Should the acetylator phenotype be determined when prescribing hydralazine for hypertension. Eur $\mathcal{f}$ Clin Pharmacol (in press).

Ramsay LE. Diuretic and beta-blocker in hypertension-then what? $f R$ Coll Physicians Lond 1980;14:249-53.

f $1982 ; 284: 1602-4$, Freestone S. Hydralazine once daily in hypertension. Br Med Zacest $R$, Koch-Wese

and hypotensive action. Clin Pharmacol Ther $1972 ; 13: 420-5$.

(Accepted 8 fune 1984) 